\title{
Pemanfaatan Website dan Media Sosial Untuk Meningkatkan Brand Awareness Terhadap Pusat Pelatihan dan Pedesaan Swadaya (P4S) Desa Karang Melok, Bondowoso
}

\author{
Oktalia Juwita $^{1}$, Priza Pandunata ${ }^{2}$, Soekma Yeni Astuti ${ }^{3}$ \\ ${ }^{1,2}$ Prodi. Sistem Informasi, Fakultas Ilmu Komputer \\ ${ }^{3}$ Prodi. TV \& Film, Fakultas Ilmu Budaya \\ 1,2,3 Universitas Jember \\ 1 oktalia.juwita@gmail.com, ${ }^{2}$ priza@unej.ac.id, ${ }^{3}$ ysoekma@gmail.com
}

\begin{abstract}
ABSTRAK
Pusat Pelatihan Pertanian dan Perdesaan Swadaya (P4S) adalah salah satu kelompok tani yang diketuai oleh Bapak Buharto di desa Karang Melok, kecamatan Tamanan, kabupaten Bondowoso. Kegiatan utama dari P4S adalah memberikan pelatihan untuk menjalankan pertanian organik dan pembuatan pupuk organik. Permasalahan yang dihadapi P4S adalah pada kegiatan pemasaran dan proses pendaftaran bagi kelompok atau individu yang ingin mengikuti pelatihan. Selama ini pemasaran yang dilakukan oleh $\mathrm{P} 4 \mathrm{~S}$ adalah dengan cara konvensional yaitu dari mulut ke mulut. Pendaftaran hanya dapat dilakukan secara langsung melalui telpon tanpa adanya proses pendataan. Upaya yang dapat dilakukan untuk pemasaran dan meningkatkan brand awareness P4S adalah dengan membuatkan website dan akun di media sosial (facebook), dan kemudian disosialisasikan penggunaanya ke pengelola/anggota $\mathrm{P} 4 \mathrm{~S}$.
\end{abstract}

Kata kunci : P4S; pemasaran; brand awareness; website; media sosial

\section{ABSTRACT}

"Pusat Pelatihan Pertanian dan Perdesaan Swadaya (P4S)" is one of the farmer groups chaired by Mr. Buharto in Karang Melok village, Tamanan, Bondowoso. The main activity of P4S is to provide training to runing organic farming and making organic fertilizer. The problems faced by P4S are marketing activities and the registration process for groups or individuals who want to take part in the training. So far the marketing carried out by P4S is in the conventional way, which is word of mouth. Registration can only be done directly by telephone without the data collection process. Efforts that can be made for P4S in marketing activities and increasing brand awareness are by creating websites and account on social media (in this case Facebook), and then disseminated its use to members of P4S.

Keywords : P4S; marketing; brand awareness; website; social media

\section{PENDAHULUAN}

Desa Karang Melok memiliki tingkat laju di bidang teknologi informasi sangat pesat, namun pemahaman mengenai pemanfaatan dan bahayanya masih sangat rendah sehingga penggunaannya hanya terbatas sebagai sarana komunikasi dan hiburan saja. Menurut Sholikha, adanya teknologi seharusnya dapat dimanfaatkan untuk memperoleh informasi dan ilmu 
pengetahuan yang lebih banyak dan bermanfaat [1].

Salah satu potensi yang dimiliki oleh desa Karang Melok adalah Pusat Pelatihan Pertanian dan Perdesaan Swadaya (P4S) yang dikelola oleh kelompok tani Bintang Tani Sejahtera dan diketuai oleh Bapak Buharto, salah satu petani di desa Karang Melok yang telah banyak memiliki inovasi di bidang pertanian dan telah mendapatkan juara I pemilihan petani teladan Jawa Timur 2013. Kegiatan utama dari $\mathrm{P} 4 \mathrm{~S}$ adalah memberikan pelatihan untuk pengelolaan pertanian organik dan pembuatan pupuk organik (Gambar 1). Di P4S juga disediakan berbagai fasilitas untuk pelatihan (Gambar 2) dan juga penginapan untuk para peserta pelatihan dari luar kota.
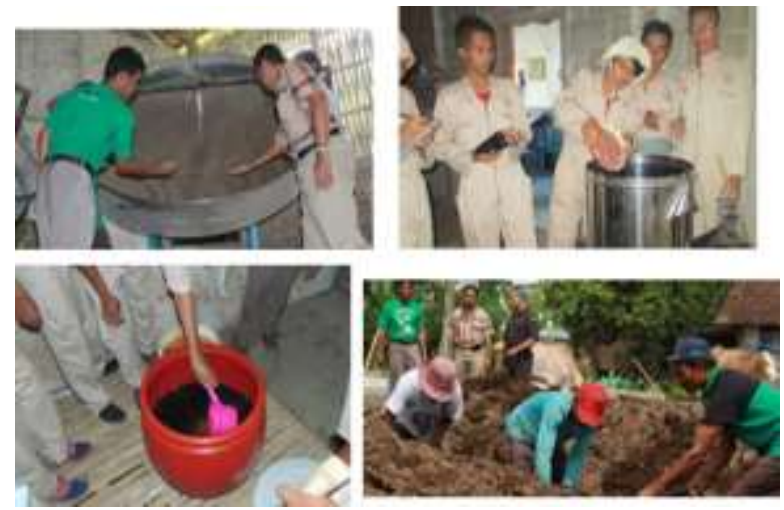

Gambar 1. Kegiatan Pelatihan di P4S

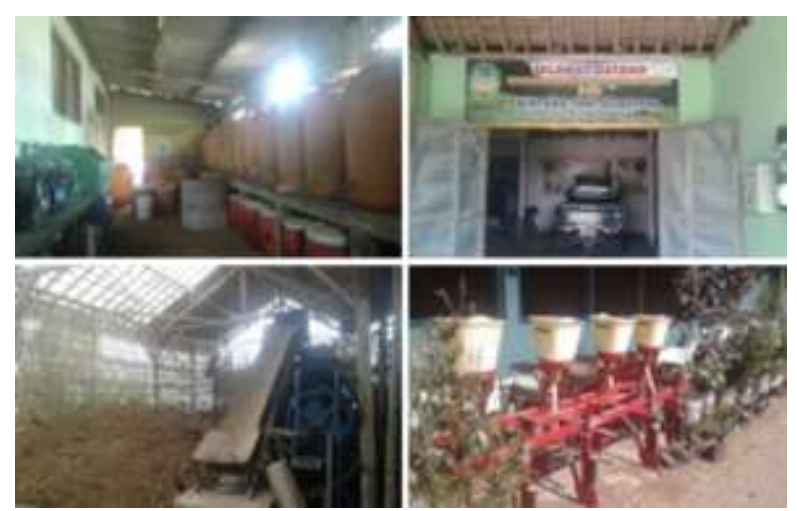

Gambar 2. Fasilitas Pelatihan
Permasalahan yang dihadapi P4S adalah pada kegiatan pemasaran dan proses pendaftaran bagi kelompok atau individu yang ingin mengikuti pelatihan. Selama ini pemasaran yang dilakukan oleh P4S adalah dengan cara konvensional yaitu dari mulut ke mulut. Pendaftaran hanya dapat dilakukan secara langsung melalui telpon tanpa adanya proses pendataan.

Untuk mengatasi permasalahan tersebut, maka solusi yang dapat ditawarkan kepada $\mathrm{P} 4 \mathrm{~S}$ adalah pembuatan website untuk memfasilitasi dan mempermudah Bintang Tani Sejahtera dalam meng-update kegiatan-kegiatan pelatihan dan memfasilitasi pendaftaran untuk mengikuti pelatihan di Bintang Tani Sejahtera. Selain itu website yang akan dibuat dan dikembangkan tersebut juga akan diintegrasikan dengan media sosial (dalam hal ini Facebook) untuk meningkatkan brand awareness sehingga dapat menjangkau kalangan yang lebih luas.

Pemasaran online dapat mempengaruhi cara bersaing bagi industri kecil seperti mampu menarik dan mengidentifikasi pelanggan baru, kemampuan menciptakan brand awareness, ketersediaan bantuan pelayanan kepada konsumen, ketersediaan komunikasi online dengan pengusaha [2]. Menurut Hendry Hartanto dan Engelbertha Silalahi, media sosial dapat digunakan sebagai pelengkap bagi media tradisional untuk meningkatkan nilai brand image perusahaan di masyarakat karena selain berpengaruh signifikan, media sosial juga efisien sehingga perusahaan tidak perlu mengeluarkan biaya yang besar dalam 
kampanye iklan. Media sosial memiliki atraktivitas, kelengkapan informasi, kejelasan informasi, dan kemudahan akses yang lebih baik dibandingkan media tradisional sehingga perusahaan akan lebih baik jika mampu menggunakan media sosial mereka dengan lebih efektif dan terencana sehingga mampu memberikan pengaruh yang lebih besar ke brand image perusahaan [3]. Untuk melengkapi website yang akan dibangun dan halaman di akun media sosial tersebut, akan dibuat juga beberapa foto/gambar serta video yang akan diunggah.

\section{METODE KEGIATAN}

Program kegiatan pengabdian ini dilakukan di Desa Karang Melok, kecamatan Tamanan, kabupaten Bondowoso yang merupakan salah satu desa binaan KKN Universitas Jember di kabupaten Bondowoso. Sasaran program kegiatan pengabdian ini ditujukan untuk kelompok tani yang tergabung dalam Pusat Pelatihan Pertanian dan Perdesaan (P4S). Kegiatan pengabdian ini akan dilakukan selama kurang lebih 3 bulan (Oktober - Desember 2018).

Adapun kegiatan yang akan dilakukan adalah sebagai berikut :

- Tahapan survey dan wawancara guna menggali potensi yang ada di desa Karang Melok. Dari beberapa potensi yang didapat dan berdasarkan latar belakang keilmuan dari anggota tim kegiatan pengabdian serta berdasarkan tren pasar yang ada, maka dipilihlah kelompok tani yang terhimpun dalam P4S.

- Tahapan selanjutnya adalah survey dan wawancara langsung pada ketua P4S yaitu Bapak Buharto. Tahapan ini adalah bertujuan untuk mengetahui dan menganalisa permasalahan yang dihadapi oleh Bintang Tani Sejahtera secara lebih spesifik.

- Tahap pembuatan website. Pembangunan website menggunakan System Development Life Cycle (SDLC) model Waterfall karena mudah dipahami dan digunakan dalam proses pembuatannya [4]. Model waterfall memiliki 6 tahapan, yaitu Requirement, Design, Implementation, Testing, Deployment, Maintenance [5].

- Tahap analisa kebutuhan dari pembuatan akun/halaman media sosial.

- Sosialisasi dan pelatihan penggunaan website dan akun media sosial yang telah siap jalan dan siap dilanjutkan.

\section{KARYA UTAMA}

Hasil dari kegiatan pengabdian kepada masyarakat ini adalah antara lain :

1. Adanya website dengan nama www.bintangtanisejahtera.com sebagai sarana informasi tentang kegiatan pelatihan yang dilakukan di P4S dan juga sarana pendaftaran untuk pihak luar yang ingin mengikuti pelatihan.

2. Adanya akun di media sosial Facebook dengan nama P4S Bintang Tani Sejahtera.

3. Website yang dibangun, diintegrasikan dengan email dan juga akun Facebook tersebut sehingga memudahkan pengelola nantinya dalam pemasaran dan pendataan pendaftaran peserta pelatihan.

4. Melalui website dan akun Facebook tersebut, pengelola P4S dapat lebih 
mudah untuk mengenalkan tempat pelatihannya serta sarana yang disediakan di tempat pelatihan tersebut

5. Pengelola P4S juga dapat mendata pendaftar serta mengatur jadwal pelatihan lebih mudah.

\section{ULASAN KARYA}

Kegiatan pengabdian kepada masyarakat ini, sangat bermanfaat terutama bagi kelompok tani Bintang Tani Sejahtera dalam memasarkan dan mengelola P4S. Website dan akun media sosial yang dibangun, akan sangat membantu untuk P4S mengenalkan kegiatan-kegiatan pelatihan yang mereka selenggarakan.

Kendala yang dihadapi dalam pembuatan website dan akun Facebook ini adalah kurang terbukanya pihak pengelola P4S. Kekhawatiran akan dicurinya ilmu yang mereka miliki secara lebih luas yang menyebabkan kekurang terbukaan tersebut. Kendala lain adalah mereka juga belum memiliki pengetahuan tentang bagaimana meneruskan mengelola website dan akun Facebook tersebut.

Upaya yang dilakukan untuk mengatasi kendala tersebut adalah memberikan pemahaman tentang bagaimana manfaat dari berbagi ilmu terhadap sesama dan apa hasil yang dapat mereka dapatkan apabila P4S tersebut lebih dikenal di masyarakat luas.

Kendala lain yang mungkin muncul nantinya adalah di sumber daya manusia. Agar dapat konsisten berkarya sambil meneruskan mengenalkan P4S melalui website dan akun Facebook tersebut, mungkin akan terhambat. Untuk itu dibutuhkan minimal satu anggota yang khusus ditugaskan sebagai admin pengelola website dan akun Facebook.

\section{DAMPAK DAN MANFAAT KEGIATAN}

Manfaat dari kegiatan pengabdian kepada masyarakat ini antara lain :

- Para anggota kelompok tani Bintang Tani Sejahtera yang mengelola P4S memperoleh pengetahuan baru tentang pemanfaatan teknologi informasi

- P4S dapat lebih meningkatkan brand awareness pada masyarakat luas.

- Memudahkan pengelola P4S dalam mendata dan mengatur jadwal pelatihan bagi bara kelompok atau individu yang mendaftar untuk emngikuti pelatihan pengelolaan pertanian organik dan pembuatan pupuk organik.

\section{KESIMPULAN}

Target yang diharapkan dari kegiatan pengabdian kepada masyarakat ini adalah lebih memudahkan pengelola $\mathrm{P} 4 \mathrm{~S}$ dalam mengenalkan kegiatan-kegiatan pelatihan yang mereka laksanakan. Dengan mudahnya kegiatan pemasaran yang dilakukan, maka diharapkan juga meningkatnya brand awareness dari masyarakat terhadap adanya P4S ini. Selain itu, dengan adanya website, maka penerimaan pendaftaran dan pengaturan waktu pelatihan dapat lebih mudah. 
Saran yang diberikan supaya website dan akun media sosial ini dapat tetap konsisten berjalan adalah penugasan khusus pada anggota kelompok tani bintang tani sejahtera untuk menjadi admin.

\section{PENGHARGAAN (opsional)}

Terimakasih atas bantuan dana Dirjen Riset dan Pengabdian Masyarakat (DRPM), dan Universitas Jember sehingga kegiatan pengabdian kepada masyarakat ini dapat terselenggara. Terimakasih juga pada kelompok tani Bintang Tani Sejahtera khususnya pengelola P4S dan Bapak Buharto selaku ketua kelompok tani di desa Karang Melok, Kabupaten Bondowoso - Jawa Timur, atas kerjasama dan bantuannya dalam pelaksanaan kegiatan ini.

\section{DAFTAR PUSTAKA}

[1] S. Sholikha, "Penerapan teknologi informasi dalam pendekatan saintifik pada mata pelajaran ekonomi," Pros. Semin. Nas. $9 \mathrm{Mei}$ 2015 penting, pp. 375-383, 2013.

[2] N. Kreatif et al., "Strategi Digital Marketing Dan Implikasinya Pada," no. April 2015, 2012.

[3] H. Hartanto and E. Silalahi, "Efektivitas Penggunaan Media Sosial Untuk Meningkatkan Brand Awareness , Functional Brand Image, Dan Hedonic Brand Image Dari Produk - Produk Samsung," pp. 187-203, 2013.

[4] Y. Firmansyah and Udin, "Penerapan Metode SDLC Waterfall Dalam Pembuatan Sistem Informasi Akademik Berbasis Web Studi Kasus Pondok Pesantren AlHabi Sholeh Kabupaten Kubu Raya , Kalimantan Barat," $J$. Teknol. Manaj. Inform., vol. 4, no. 1, pp. 185-191, 2018.

[5] R. Lewallen, Software Development Life Cycle Models, vol. 6, no. 1. 2005. 